\title{
Realia in classes of English as an additional language: creating and evaluating teaching aids
}

Materiais autênticos em aulas de Inglês como língua adicional: criando e avaliando materiais didáticos

\author{
Cristina Becker Lopes Perna1 ${ }^{1}$, Aline Jéssica Antunes² \\ Editor-in-Chief. Pontifícia Universidade Católica do Rio Grande do Sul (PUCRS). Porto Alegre, RS, Brasil. \\ Pontifícia Universidade Católica do Rio Grande do Sul (PUCRS). Porto Alegre, RS, Brasil. aline.antunes@edu.pucrs.br.
}

It is an honor to announce the $10^{\text {th }}$ volume, issue 2, of Brazilian English Language Teaching Journal (henceforth BELT + ). The articles and didactic sequences of the latest edition of BELT+ explore new teaching materials, focusing mainly on its creation processes. In the articles, one may find discussions about the use of realia in the language classroom and a review article on Corpus Linguistics, which we believe is a good resource to help teachers in the aforementioned process. Moreover, in the paragraphs below, you can read a brief summary on the papers and on the thought-provoking didactic activities presented in this edition of BELT + .

Melo introduces her article, "Didactic materials applied in English language teaching focused in the writing of the Supervised Internship Reports", as an analysis of statements written by undergraduate students at the end of their period of practicum in elementary or high schools. The purpose of these academic texts is to reflect upon teaching activities. Considering the co-construction of meaning proposed by Bakhtin, the author presents three excepts from reports and includes some comments about the methods used by the teachers, students engagement concerning the activities and the interaction among undergraduate students (teachers-to-be), students and content of English classes.

Welp, Didio and Finkler present an interesting process in order to create didactic activities. Guided by the assumption that textbooks may have a sketchy view on language as an imperative factor to social interaction, the authors based their proposal on concepts as discourse genres, sociocultural theory, 
Received on: Jan. $09^{\text {th }}, 2019$

Accepted on: Jan. $09^{\text {th }}, 2019$

Published on: Dez. $31^{\text {th }}, 2019$

Mailing address:

Cristina Becker Lopes Perna

Pontifícia Universidade Católica de Rio Grande do Sul

Av. Ipiranga, 6681

Partenon 90619-900

Porto Alegre, RS, Brasil.

scaffolding, literacy and task-based language learning. In their article "Contemporary issues in cinema and literature: the design of a task sequence for the teaching of English as an additional language", it is possible to find references of fairy tale books and movies amidst the description of the five choices they have made in order to structure the tasks, concerning theme, discourse genre and text selection.

Furthermore, in Goulart's review article, we may read about a special bias of Corpus Linguistics: the use of collocations by L2 learners, that is, non-native English speakers. "The use of collocations across proficiency levels: a literature review" provides answers to three main issues: the relation between proficiency and the use of collocations, the methodologies applied to research in this specific area, and the registers that have been investigated throughout the twenty-three papers analyzed. According to the author, among other findings, the use of collocations seems to be proportional to L2 learner's proficiency level due to the explicit teaching of units of language instead of tokens, of single words.

The didactic activities of this edition present distinct proposals to promote better communication. Zaccaron, in his "Ideas for integrating meaningful immediate repetition tasks in the English as an additional language classroom: promoting fluency", shares benefits to repetition on a new perspective, through three exercises applied in his own classes of English to non-native learners. On the other hand, Gomes combines concepts of Pragmatics regarding face-threatening and face-saving acts to design "Help the newbie!, bringing politeness theory and netiquette together in the EAL classroom", one lesson of seven tasks as a mean to improve politeness in computer-mediated communication.

We are very thankful for the authors' contributions to this edition with a focus on Realia in classes of English as an additional language, for the reviewers who took their time to evaluate the articles and we wish our readers an enjoyable and fruitful reading experience and hope that the readings may help enhance their classroom practice. 